\title{
Sharia Maqashid's Inclusive Performance and Contribution to The Sharia Non-Bank Financial Industry in Indonesia
}

\author{
Budi Sukardi \\ IAIN Surakarta, Surakarta, Indonesia \\ email: budizureydi@gmail.com \\ Fachrurazi \\ IAIN Pontianak, Pontianak, Indonesia \\ email: ferry.7co@gmail.com

\section{Supriyanto} \\ IAIN Surakarta, Surakarta, Indonesia \\ email: supriyanto.mud@gmail.com
}

\begin{abstract}
This study aims to analyze the Sharia Non-Banking Financial Industry (henceforth INKB) performance in Indonesia based on the criterion of sharia maqashid and its inclusive contribution. This study's population is the Sharia IKNB, with the samples include sharia insurance companies, sharia finance companies, sharia pension funds, and pawnshop companies. The data in this study were analyzed using the Simple Additive Weighting method. The study results show the highest five ranks of Sharia Maqashid Index performance calculation, namely, in respective order, DPLK Muamalah, Reindo Syariah, Asuransi Takaful Indonesia, Sarana Multigriya Finansial, and lastly is Pegadaian Indonesia. To overcome the structural poverty that has been a prominent unfinished issue and often neglected by the state, it requires the ability and sensitivity to respond to the low class' turmoil by the sustainable economy, environment, and financial industry media. The Sharia IKNB must contribute to the public in becoming the frontline in improving the structural poverty system and leading industry in achieving the highest sharia objective, to maintain the life sustainability of humans, nature, economic resource, and other life aspects of the society.
\end{abstract}

Keywords: Sharia IKNB; Sharia maqashid; Simple Additive Weighting

\begin{abstract}
Abstrak: Penelitian ini bertujuan untuk menganalisis kinerja Industri Keuangan Non Perbankan Syariah (selanjutnya INKB) di Indonesia berdasarkan kriteria maqashid syariah dan kontribusinya yang inklusif. Populasi penelitian ini adalah IKNB Syariah, dengan sampel perusahaan asuransi syariah, perusahaan pembiayaan syariah, dana pensiun syariah, dan perusahaan pegadaian. Data dalam penelitian ini dianalisis menggunakan metode Simple Additive Weighting. Hasil studi menunjukkan lima peringkat tertinggi penghitungan kinerja Indeks Maqashid Syariah, yaitu di masing-
\end{abstract}

Economica: Jurnal Ekonomi Islam - Volume 10, Nomor 2 (2019) 
masing urutan, DPLK Muamalah, Reindo Syariah, Asuransi Takaful Indonesia, Sarana Multigriya Finansial, dan terakhir adalah Pegadaian Indonesia. Untuk mengatasi kemiskinan struktural yang selama ini menjadi isu menonjol yang belum terselesaikan dan sering diabaikan oleh negara, diperlukan kemampuan dan kepekaan dalam merespon gejolak kelas bawah oleh media ekonomi, lingkungan, dan industri keuangan yang berkelanjutan. IKNB Syariah harus berkontribusi kepada masyarakat menjadi garda terdepan dalam memperbaiki sistem kemiskinan struktural dan industri unggulan dalam mencapai tujuan syariah yang setinggi-tingginya, menjaga keberlanjutan kehidupan manusia, alam, sumber daya ekonomi, dan aspek kehidupan masyarakat lainnya.

Kata Kunci: IKNB Syariah; Maqashid syariah; Pembobotan Aditif Sederhana 
Sharia Maqashid's Inclusive Performance and Contribution ...

\section{Introduction}

The Non-Banking Financial Industry is the financial industry apart from the banking and capital market that offer financial products and indirectly withdraws funds from the people (Muchlasin, 2018). The Non-Banking Financial Industry (IKNB) consists of insurance, venture capital, pawnshops, pension funds, microfinance institutions (LKM), Indonesian Export Funding institution Indonesia Eximbank (LPEI), and multi-infrastructure facilities (SMI). The Non-Banking Financial Industry holds a vital role in the economy to provide funding, protection against financial loss, temporary equity participation, investment, liquidity support, and the establishment of 140 IKNB companies. The Sharia IKNB is a part of the financial service institution closely related to non-banking financial activities in the insurance industry, pension funds, funding institutions, and other financial service institutions sharia principles.

Although Indonesia's development of the non-banking financial industry is decreasing global-wide, Indonesia has a significant difference from other Islamic countries. The sharia financial activities development in Indonesia focuses on the market drive to fulfill society's needs in the real factors, which is different from Saudi Arabia, Malaysia, and Iran that focus more on the financial sector and predominant government intervention towards the sharia financial development. The competition between sharia and conventional finances also affects the Sharia financial industry's growth that increases around 15-30\% annually (Antonio, Sanrego, and Taufiq 2012).

The increase in the growth of the sharia financial industry in Indonesia requires performance measurement and monitoring systems to determine the prospect of the sustainable sharia financial industry in the future (Kuppusamy, Saleh, dan Samudhram 2010). The measurement system is significant to analyze the sharia's highest purpose towards the sustainable development of the sharia financial industry in Indonesia. The

Economica: Jurnal Ekonomi Islam - Volume 10, Nomor 2 (2019) 
implementation of AFTA and MEA agreements requires the sharia financial industry to change the small community's social order of market players, family roles, ethnicity, and religious Sufism relations to provide trust and maintain the relationship among stakeholders (Chapra dan Ahmed 2008).

Currently, companies use financial ratios, such as CAMELS and EVA, to measure the performance. The financial ratio, such as the rate of assets (ROA) and rate of equity (ROE), is a favorable indicator in measuring bank performance (Bonin, Hasan, dan Wachtel 2005). Nevertheless, the performance measurements still have some weaknesses from the financial sector's point of view; the measures do not take non-financial factors into account, which positively affect the financial performance in the long term (Seçme, Bayrakdaroğlu, dan Kahraman 2009). Some studies suggest that the non-financial factors are better predictors in determining a long-term performance (Hussain dan Hoque 2002).

Based on the above findings, there is a need to measure the Sharia financial industry's performance on its highest goal, which focuses on the financial ratio or profitability and the stakeholders' benefit social welfare (Yuwono 2004). Attempts by Dzuljastri dan Taib, Kuppusamy et al., Hameed et al. to measure the Sharia financial industry's performance prove that the maqashid index can become a strategic approach to describe that the sharia financial industry's performance is universal and is applicable as a comprehensive strategy of policies (Mohammed dan Razak 2008; Hameed, Alrazi, dan Pramono 2004; Kuppusamy, Saleh, dan Samudhram 2010).

As for the Indonesian non-banking sharia financial industry, there has been a very rare measurement of sharia maqashid performance. Some research only focuses on the index measurement by emphasizing the criteria and alternative of the Sharia maqashid dimension rather than the economic, environmental, and social performance indicators (Siddiqui 2001). Siddiqui's three indicator concepts are the development result of the maqashid paradigm that has orientation on Sharia finance's sustainability in identifying 
the organization's principles and objectives, framing a long-term image towards the sharia finance and business.

In facing the global economic competition challenge, the sharia financial industry has not entirely contributed to creating global welfare, mutual competition and partnership (competition-competitive-mutual), social welfare, building the civilization, and maintaining Islamic values (Swasono 2010; Iqbal, Ahmad, dan Khan 1998). Currently, the non-banking sharia financial industry has not reached its maximum capacity to achieve sharia's ultimate objectives that ensure welfare and prosperity in life and the hereafter (falah) for the people. At the same time, the industry has not contributed to the Indonesian economic performance national-wide.

The implementation analysis of the ultimate objectives and advantages of the sharia IKNB in Indonesia requires exploration and identification of the manifestation of the objects and its contribution of sharia maqashid values towards the sustainability of the sharia non-banking financial industry in Indonesia. This study's problems are 1). How is the performance of the Sharia non-banking financial industry in Indonesia based on the sharia maqashid criteria? 2). What is the inclusive contribution of sharia maqashid towards the Sharia Non-banking Financial Industry in Indonesia?

\section{Literature review}

\section{Maqashid syariah}

The sharia maqashid derives from two words, namely maqashid and sharia. Maqashid is the plural form of maqshad, which means objective and goal; on the other hand, sharia means Allah's rules that have become the guidance to achieve true happiness in life and the hereafter (Shidiq 2009; Rohmati, Anggraini, dan Widiastuti 2018). The term sharia maqashid refers to the objectives to achieve upon the law stipulation in Islam (Jaya 1996). 
Wahbah al-Zuhaili defines the sharia maqashid as the obectives and meanings maintained by syara' in most of its law base, if not al, or the final goal of the sharia and secrets placed by the syara' in each of its law (Zuhaili 1997). Wahbah al-Zuhaili also explains that knowledge on the sharia maqashid is an urgent issue (dharuri) for a mujtahid to conceive and nash and producing the law's istinbath, and for other people to comprehending the secrets of sharia (Zuhaili 1997).

Fazlurrahman defines maqashid as objective or deliberateness; on the other hand, he defines al-syariah (sharia) as the path heading to the water spring, or in another way, it refers to the path to the life's main source (Fazlurrahman 1984). Imam al-Syatibi explains the purpose of sharia is to achieve the welfare and benefit for all humankind; this means that all laws from Allah have particular purposes, as law without purpose will burden humankind with the impossible task (Al-Syatibi 1900).

The importance of sharia maqashid has several considerations, namely:

a. Islamic laws derive from God's revelation and are for all humankind; therefore, the laws will always encounter with the social change.

b. Historically, the sharia maqashid takes the exemplary from the Prophet Muhammad SAW, his companions, and the first generation of the mujtahid.

c. Knowledge and understanding of the sharia maqashid is the success keyfor the mujtahid in performing the ijtihad, as the law's objective serves the principples for all transactions among people (Shidiq 2009).

Imam al-Syatibi states that humankind's benefit includes everything related to the human's fortune, the fulfillment of human needs, and the achievement of any demands from the human's emotional and intellectual qualities within an absolute definition (Al-Syatibi 1900). The basic needs of 
human life are to serve the purpose of benchmarking the advantages and disadvantages of any action and the law's primary objective.

There are three levels of human needs according to al-Syatibi, namely the dharuriyat (primary need), hajiyat (secondary need), and tahsiniyah (tertiary need) (Al-Syatibi 1900; Rohmati, Anggraini, dan Widiastuti 2018). To improve the performance measurement of the sharia maqashid in the sharia business, Abu Zahrah explains the three dimensions as follow:

a. Tahdhib al-Fard (individual learning) aims to prove the distribution of knowledge and skill and embed them into the individual values to develop the spiritual side.

b. Iqamah al-'Adl (justice and equity manifestation) requires the Sharia banks to ensure the fair transaction of all business activities, including product, price, and contract terms and conditions.

c. Jalb al-Maslahah (public interest achievement) requires the Sharia banks to embed the public interest fulfillment (Zahrah 1958).

\section{Sustainable development}

Accordng to Emil Salim, sustainable development aims to improve humankind's welfare and fulfill their needs and aspiration (Salim 1990). Sustainable development focuses on the distribution of development among generation at present and in the future. According to Heal, the sustainable concept includes at least two dimensions: the time dimension, because sustainability is about what happen in the future, and the interactional dimension between economy, natural resources, and environmental systems (Heal 1999).

Sutamihardja explains that the objectives of sustainable development are to achieve:

a. To achieve the inter-generation equity of the development results, the use of natural resources for the development must pay attention

Economica: Jurnal Ekonomi Islam - Volume 10, Nomor 2 (2019) 
to the fair limits within the ecosystem control or environmental system, direct the attempts to use replaceable resources, and minimize the usage of unreplaceable resources.

b. To safeguard the natural resources preservation and the environment within it and avoid any distraction towards the ecosystem to guarantee its well-being for the next generation.

c. The usage and management of natural resources are for economic growth to achieve the fair use of sustainable natural resources from one generation to the next.

d. To maintain sustainable public welfare at present and in the future (inter-temporal welfare).

e. To maintain the benefit as the effect of development or the natural resources and environmental management with a long-term impact among generations.

f. To maintain the quality of human life from one generation to the next according to its natural habitat (Sutamihardja 2004).

Based on the economic point of view, Fauzy explains that there are at least three main reasons for having a sustainable economy:

a. Moral base; the present generation benefits from the natural resources and environment in goods and service. Therefore, from the moral point of view, there is a need to ensure the next generation's resources' availability. The moral obligation includes the activity to avoid any harmful extraction of the natural resources, causing environmental damage and eliminating the next generation's chance to indulge in similar service.

b. The ecological reason; the biodiversity has a supreme value; therefore, the economic activities must not harm the ecological function by utilizing the natural resources and environment. 
c. The economic reason; there are still some arguments on this aspect. The economic activities have not proven the ability to fulfill sustainability criteria. Therefore, a sustainable economy's complex dimension limits the measurement only on the intergeneration welfare maximization (Fauzi 2004).

Khurshid Ahmad formulates four principles of Islamic teaching as the philosophical basis of Islamic development as follow:

a. Tawheed; a practice to put the fundamental relationship between humankind and Allah, and among humankind.

b. Rububiyah; fundamental rules from Allah that further set the Islamic development.

c. Khalifah; an explanation of the status and role of humankind as Allah's representative on earth. The obligation includes humankind's role as a Muslim and society member. The concept produces a definition of guardianship, morals, politics, economy, and other social organization principles.

d. Tazkiyah; as an explanation of the ultimate mission of Allah's messenger to purify humankind in the relationship with Allah, other people, natue and environment, society, and the country (Ahmad 1976).

Chapra offers five Islamic-based economic development policies as follow:

a. To activate the human factor in implementing the maqashid in a conducive political environment. A significant allocation and efficient distribution of equal resources require humankind to provide the best effort and use the rare resources wisely and at a high-efficient rate. 
b. To reduce wealth concentration as the main issue of equitable development.

c. To restructure the economy by relocating required resources and rearranging economic aspects (incuding the consumption or private sector, government finance, capital formation, and production) to achieve fair development.

d. To restructure the finance to achieve urban and city development in resolving the main economic issues, including unemployment and wealth concentration resulting from the absence of developmental preparation and funding.

e. The establishment of strategic policies sets the structural change in the economy to fulfill the needs, reduce the unemployment rate, and increase economic growth without creating an imbalance between the micro and macro economy (Chapra 1993).

\section{The relationship between sharia maqashid and sustainable development}

Sharia maqashid is the most prominent factor that has double roles in achieving humankind's welfare, and provide philosophical and rational dimensions towards the sharia banking financial system. The sharia maqashid provides reasonable and substantial thought patterns in viewing agreements and sharia banking products, and avoid any damage and danger of frauds from the creditors and debtors (Wasyith 2017).

Through the sharia maqashid, the sharia banking products and finance can improve well and responds to the fast-changing business growth. A conducive sharia maqashid requires humanity motivation through moral injection in fulfilling self-needs to maintain the social interest although it may require the self-interest override. 
To establish moral values, Chapra considers realistic improvements as follow:

a. Socio-economic justice; the policies must refer to the implementation of socio-economic justice.

b. Moral transformation towards each individual to ensure their action always puts the social interest in front (Chapra 2001).

Sharia banking performance measurement must go through the conventional approach and measure the sharia maqashid objectives to indicate any violating transaction against the sharia principles. The practice will affect the flexibility, dynamics, and creativity in the decision-taking, social activities, and welfare.

The main purpose of sharia is to promote the human welfare based on the faith (din), soul (nafs), thought ('aql), descendant (nasl), and wealth (mal) (Rohmati, Anggraini, dan Widiastuti 2018). The five elements' assurance will fulfill the public interest and welfare as the development's final goal.

The Sharia Non-Banking Financial Industry must set educational and training programs that improve the labors' knowledge and skill and provide appropriate moral values. Besides, the industry must also provide information on their products for the shareholders.

The Sharia IKNB must ensure all of its businesses are free from any injustice practices, such as riba (including usury and interest), fraudulence, and corruption. Indirectly, the IKNB must use its profit wisely for the public interest to reduce the social discrepancy and circulate and share the profit fairly.

The Sharia IKNB must prioritize the business activities that provide more benefits for society. The activities include the ones related to the society's basic needs, such as investments on significant sectors and housing project funding. 
Siddiqi and Shahul emphasize that the sharia finance industry does not aim at achieving a maximum profit (Siddiqi 1980; Shahul 2001). Sharia banking must focus on the life's success and hereafter based on the sharia maqashid (Rohmati, Anggraini, dan Widiastuti 2018). The values of sharia maqashid must become the final goal to promote the welfare, benefits, and the elimination of life's pain (Jauziyah 1973; Yubi 1998; 'Asyur 2000; Fasy 1993). Mannan also explains that sharia banking must contribute to social welfare and does not achieve maximum profit (Mannan 1980).

To achieve the sharia maqashid, the Sharia IKNB must be able to maintain the purity of faith (din), soul (nafs), thought ('aql), descendant (nasl), and wealth (mal) (Al-Ghazali 1991; Chapra 2001; Rohmati, Anggraini, dan Widiastuti 2018). In practice, the sharia maqashid achievement in the sharia financial industry is based on the fulfillment in individual learning, justice embodiment, and public interest's fulfillment (Zahrah 1958). The measurement is to find out the responsibility rate and expected obligation from the sharia financial industry.

The sharia financial industry's responsibility towards the public and society's interest affect its sustainability in the national development and economy. Sustainable development aims to improve social welfare and provide fair outcome for the current generation and the future's (Salim 1990). Fauzi explains three reasons for the need for sustainable economic development: to maintain the natural resources, to maintain the ecological and environmental values, and to keep the social welfare (Fauzi 2004).

Therefore, sustainable development has three aspects: the economic sustainability to produce goods and services, environmental sustainability to maintain the natural resources that include the financial sources, and social sustainability as a system to achieve equality, justice, welfare, and accountability (Fauzi 2004). Sustainable development to achieve equality between the environment and economic sector has a close correlation with the sharia maqashid values in securing the next generation. 
Sharia Maqashid's Inclusive Performance and Contribution ...

\section{Review of previous literature}

Mohammed et al. evaluated the sharia banking performance using the maqashid index by measuring Islamic banks' performance based on the the maqashid framework developed using the SAW method in six years (20002005). The result of the study shows that not any of the banks have successfully achieved the high performance of sharia maqashid, therefore, it requires a reevaluation on the objective and goal (Mohammed dan Razak 2008).

Besides, Kuppusamy et.al. also evaluated Islamic banks's performance by using sharia conformity and profitability model with four banks sample from Malaysia, Bahrain, Kuwait, and Jordan from 2001 to 2004. The model used is the sharia conformity and profitability (SCnP). The SCnP is a combination of the conventional and sharia financial performance indicators. The sharia conformity consists of the sharia investment ratio, Islamic income ratio, and profit-sharing ratio. On the other hand, bank profitability includes ROA, ROE, and profit margin ratio. The study results show that the majority of sharia banking can achieve high profit and has good sharia conformity (Kuppusamy, Saleh, dan Samudhram 2010).

Mohammed and Taib's research show a performance measurement result of twenty-four Islamic and conventional banks using the sharia maqashid model. The research analysis used the Mann Whitney U-Test and SAW from 2000-2005 by two models. The first model is the PMMS model consisting of ten ratios referring to Abu Zahrah's sharia maqashid (Tahdzib alFard, Iqomat Al-Adl, and Maslahah). The second model is the CBPM model consisting of financial ratios such as Return of Assets (ROA), Net Interest Income (NII), and Liquidity (LIQ). The research results show that sharia banking measurement using the PMMS model is higher than the conventional banks. As for the CBPM model, the sharia banking performance is lower than the conventional ones in terms of ROA and NII variables. Nevertheless, sharia banking has higher achievement in the LIQ variable than the conventional 
ones. In other word, Islamic banking has a higher liquidity ratio than conventional ones (Mohammed dan Taib 2015).

This research's distinctive aspect lies in the object that is the sharia nonbanking financial industry instead of sharia banking.

\section{Methods}

This research's method is exploratory, providing ideas, insight, and understanding of the issues faced by the sharia non-banking financial industry in Indonesia (Santoso dan Tjiptono 2001). This experimental research used the experience pattern survey by discussing with the expert from the internal and external organizations. The expert includes Sharia Financial Industry officers, the Boards of Directors of the Sharia Financial Industry, MES (Sharia Economic Society) functionaries, Islamic Economic Expert Association (IAEI), Sharia Supervisor Boards (DPS), and the Islamic Decision Boards of Commision of MUI. Expert' involvement is to provide accurate and reliable information for the issue and required concept for the research.

The secondary data came from internal and external sources in the form of financial publication report of the Sharia Non-banking Financial Industry. The third stage is the pilot studies, where the research uses primary data, such as an in-depth interview result, FGD, and Focus Group Interviews.

This study's object is the sharia companies of insurance, funding, venture capital, infrastructure funding, pension funds, reinsurer, pawnshops, Indonesian export funding, and micro-finance institution. The data used in this research consists of primary and secondary data. The secondary data is from the annual financial report, Good Corporate Governance (GCG) reports of 2015-2018 published by OJK, and other supporting data, such as social activity reports of the sharia non-banking financial industry. At the same time, the primary data is from the banking experts (DPS, MUI, MES, IAEI) and the policymakers (BI, OJK, Kemenkeu) of the sharia non-banking financial industry by Focus Group Discussion method. 
The research also used the Simple Additive Weighting (SAW) approach to answer the problems related to the sharia maqashid measurement criteria. The index used in the study is the sharia maqashid developed by Mohammed and Taib, consisting of two models, PMMS and CBPM. The PMMS consists of ten ratios referring to Abu Zahrah's sharia maqashid (Tahdzib al-Fard, Iqomat Al-Adl, and Maslahah). The CBPM model consists of financial ratios such as Return of Assets (ROA), Net Interest Income (NII), and Liquidity (LIQ) (Mohammed and Taib: 2015).

The SAW method's basic concept is to find the weighted sum of the performance rating for each alternative on all attributes (Fishburn 1967; MacCrimmon 1968). The SAW method requires the decision matric normalization process (x) to a comparable scale with all existing alternative rating. This method requires the decision-maker to determine the value of each attribute. The alternative's total score is summing up all multiplication results of each attribute's ratting and value. Each attribute rating must be free of dimension, which means they have undergone the matrix normalization (Kusumadewi et al. 2006). The normalization formula is as follow:

$$
r i j=\left\{\begin{array}{cl}
\frac{x i j}{M a x \times i j} & \text { if } j \text { is an attribute benefit } \\
\frac{\mathrm{M} x \mathrm{xij}}{\mathrm{i}} & \text { if } \mathrm{j} \text { is an attribute cost }
\end{array}\right.
$$

With rij is the normalized performance rating of alternatives on attribute $\mathrm{Ci} \mathrm{Ai} ; \mathrm{i}=1,2, \ldots, \mathrm{m}$ and $\mathrm{j}=1,2, \ldots, \mathrm{n}$. Preference value alternative (vi) using the formula as follow:

Economica: Jurnal Ekonomi Islam - Volume 10, Nomor 2 (2019) 
Budi Sukardi, Fachrurazi, and Supriyanto

$$
\mathrm{Vi}_{\mathrm{i}} \sum_{j=1}^{n} \mathrm{w} \text { j rij }
$$

A higher Vi value indicates that the Ai alternative is more preferable.

\section{Result and discussion}

The Sharia Non-Banking Financial Industry (Sharia IKNB) is one of the Sharia financial industry pillars whose development can improve the Indonesian's sharia economy. The Sharia IKNB relates to insurance, pension funds, funding institution, and other financial institutions that are not against the sharia principles.

In general, the activities are similar to conventional IKNB. Nevertheless, there are some distinctive characteristics, such as the sharia-based product and transaction mechanism. Some of the activities are the one done by the Sharia Financial Institution (LKS) stipulated by the National Sharia Boards of Indonesia Ulama Council (DSN MUI): Mudharabah Funding (Qiradh), Musyarakah Funding, Ijarah Funding, Wakalah, Mudharabah Musytarakah Agreement, and Kafalah Agreement.

The initial stage is by calculating each sharia maqashid's performance ratio's percentage. Each ratio represents three performance indicators, educating individu, establishing justice, and public interest. This study's data is from the annual report of Sharia IKNB (DPLK Muamalah, Reindo Syariah, Asuransi Takaful Indonesia, Sarana Multigriya Finansial, and Pegadaian Indonesia) from 2016 to 2018, in the form of management annual report and the financial annual report. The percentage of each sharia maqashid performance ratio of the sharia IKNB is as follow: 
Sharia Maqashid's Inclusive Performance and Contribution ...

\section{The sharia maqashid performance ratio of asuransi takaful} indonesia

The Sharia Maqashid performance ratio of Asuransi Takaful Indonesia from 2016 to 2018 is as table 1 :

Table 1. The Sharia Maqashid Performance Ratio of Asuransi Takaful Indonesia

\begin{tabular}{cccc}
\multicolumn{5}{c}{ Year 2016-2018 } \\
\hline Ratio & $\mathbf{2 0 1 6}$ & $\mathbf{2 0 1 7}$ & $\mathbf{2 0 1 8}$ \\
\hline R1.1 & 0,00 & 0,00 & 0,00 \\
R1.2 & 0,00 & 0,00 & 0,00 \\
R1.3 & 0,00 & 0,00 & 0,00 \\
R1.4 & 2,21 & 0,00 & 0,00 \\
R2.1 & 31,77 & 47,64 & 56,18 \\
R2.2 & 0,00 & 0,00 & 0,00 \\
R2.3 & 100 & 100 & 100 \\
R3.1 & 1,01 & 1,17 & 0,78 \\
R3.2 & 6,04 & 3,14 & 2,03 \\
R.3.3 & 21,29 & 17,21 & 16,63 \\
\hline
\end{tabular}

Source : processed data, 2019

In the education dimension, the Asuransi Takaful Indonesia did not promote the hibah (grants), scholarship, education and training, and takaful research in 2016. The only activity done was the publication and promotion of Asuransi Takaful as the implementation of social awareness. In the dimension of Justice in Asuransi Takaful, there has not been any financing in profit sharing or partnership. However, from 2016 to 2018, Asuransi Takaful received a lawful income from the total income received during the year. In the public interest dimension, takaful insurance has made investments and social services fulfilling the public interest and prosper society.

Economica: Jurnal Ekonomi Islam - Volume 10, Nomor 2 (2019) 
Budi Sukardi, Fachrurazi, and Supriyanto

\section{The sharia maqashid performance ratio of pegadaian indonesia}

The Sharia Maqashid performance ratio of Pegadaian Indonesia from 2016 to 2018 is as table 2 :

Table 2. The Sharia Maqashid Performance Ratio of Pegadaian Indonesia

\begin{tabular}{cccc}
\multicolumn{4}{c}{ Year 2016 - 2018 } \\
\hline Ratio & $\mathbf{2 0 1 6}$ & $\mathbf{2 0 1 7}$ & $\mathbf{2 0 1 8}$ \\
\hline R1.1 & 0,03 & 0,05 & 0,11 \\
R1.2 & 0,00 & 0,00 & 0,00 \\
R1.3 & 0,61 & 0,65 & 1,46 \\
R1.4 & 3,23 & 2,74 & 2,36 \\
R2.1 & 17,17 & 8,57 & 6,05 \\
R2.2 & 0,00 & 0,00 & 0,00 \\
R2.3 & 100 & 100 & 100 \\
R3.1 & 4,72 & 5,16 & 5,26 \\
R3.2 & 0,00 & 0,00 & 0,00 \\
R.3.3 & 2,74 & 3,63 & 2,15 \\
\hline
\end{tabular}

Source : processed data, 2019

In the education dimension, Pegadaian has provided grants, scholarships, education, and training to upgrade employees' competence but has not conducted research related to pawnshops. From 2016 to 2018, Pegadaian also published and promoted pawnshops to provide public awareness of the importance of pawnshops in providing solutions to financial problems.

In the dimension of Justice in Pegadaian, there has not been financing in profit sharing or partnership. However, from 2016 to 2018, Pegadaian received lawful income from the total income received during the year. In the public interest dimension, Pegadaian have invested in and social services to fulfill the community's public interest and social welfare. Unfortunately, it has not provided social funds in the form of zakat to the community. 
Sharia Maqashid's Inclusive Performance and Contribution ...

\section{The sharia maqashid performance ratio of DPLK muamalah} indonesia

The Sharia Maqashid performance ratio of DPLK from 2016 to 2018 is as table 3:

Table 3. The Sharia Maqashid Performance Ratio of DPLK Muamalah Indonesia

\begin{tabular}{cccc}
\multicolumn{4}{c}{ Year $\mathbf{2 0 1 6} \mathbf{- 2 0 1 8}$} \\
\hline Ratio & $\mathbf{2 0 1 6}$ & $\mathbf{2 0 1 7}$ & $\mathbf{2 0 1 8}$ \\
\hline R1.1 & 0,00 & 0,00 & 0,00 \\
R1.2 & 0,00 & 0,00 & 0,00 \\
R1.3 & 0,00 & 0,00 & 0,00 \\
R1.4 & 0,00 & 0,00 & 0,00 \\
R2.1 & 1,79 & 25,85 & 29,99 \\
R2.2 & 0,00 & 0,00 & 0,00 \\
R2.3 & 100 & 100 & 100 \\
R3.1 & 5,43 & 4,72 & 5,47 \\
R3.2 & 0,00 & 0,00 & 0,00 \\
R.3.3 & 99,87 & 98,46 & 102,00 \\
\hline
\end{tabular}

Source : processed data, 2019

In the education dimension, the DPLK Muamalah has not organized grants, scholarships, education and training, research for employees, and has not even published and promoted the Muamalah DPLK as a form of providing public awareness. However, these promotions and advertisements and employee competency upgrades are possibly combined with the competency enhancement carried out at Bank Muamalah Indonesia.

In the dimension of Justice in the DPLK Muamalah, there has not been any financing in profit sharing or partnership. However, from the data for 2016 to 2018, DPLK Muamalah received lawful income from the total amount of income received during the year. In the public interest dimension, takaful

Economica: Jurnal Ekonomi Islam - Volume 10, Nomor 2 (2019) https://journal.walisongo.ac.id/index.php/economica 
insurance has invested in and social services to fulfill the community's public interest and social welfare.

\section{The Sharia Maqashid Performance Ratio of PT. Reindo Syariah Indonesia}

The Sharia Maqashid performance ratio of PT Reindo Syariah Indonesia from 2016 to 2018 is as table 4 :

Table 4. The Sharia Maqashid Performance Ratio of PT. Reindo Syariah Indonesia

\begin{tabular}{cccc}
\multicolumn{4}{c}{ Year 2016-2018 } \\
\hline Rasio & $\mathbf{2 0 1 6}$ & $\mathbf{2 0 1 7}$ & $\mathbf{2 0 1 8}$ \\
\hline R1.1 & 0,00 & 0,00 & 0,00 \\
R1.2 & 0,00 & 0,00 & 0,00 \\
R1.3 & 0,00 & 0,00 & 0,00 \\
R1.4 & 11,01 & 7,25 & 6,77 \\
R2.1 & 0,00 & 0,00 & 0,00 \\
R2.2 & 0,00 & 0,00 & 0,00 \\
R2.3 & 100 & 100 & 100 \\
R3.1 & 3,69 & 5,45 & 3,49 \\
R3.2 & 26,06 & 16,48 & 9,47 \\
R.3.3 & 69,87 & 71,46 & 75,41 \\
\hline
\end{tabular}

Source : processed data, 2019

In the education dimension, PT. Reindo Syariah Indonesia has not organized grants, scholarships, education and training, research for Reindo Syariah employees. Nevertheless, from 2016 to 2018, it has published and promoted Reindo Syariah, a Reinsurance company, as a form of providing public awareness.

In the dimension of Justice, PT. Reindo Syariah has not done financing in the form of profit-sharing or partnership and has not made any reserves for the profit that has not been distributed to customers from the difference in the 
profit-sharing deficiency. However, from 2016 to 2018, PT. Reindo Syariah received a lawful income from the total income received during the year. In the public interest dimension, takaful insurance has made investments and social services fulfilling the public interest and prosper society.

\section{The Sharia Maqashid Performance Ratio of PT. Sarana}

\section{Multigriya Finansial (Persero) Indonesia}

The Sharia Maqashid performance ratio of PT. Sarana Multigriya Finansial (Persero) Indonesia from 2016 to 2018 is as table 5:

Table 5. The Sharia Maqashid Performance Ratio of PT. Sarana Multigriya Finansial

(Persero) Indonesia Year 2016 - 2018

\begin{tabular}{cccc}
\hline Ratio & $\mathbf{2 0 1 6}$ & $\mathbf{2 0 1 7}$ & $\mathbf{2 0 1 8}$ \\
\hline R1.1 & 0,02 & 0,02 & 0,29 \\
R1.2 & 0,00 & 0,34 & 0,34 \\
R1.3 & 0,14 & 0,34 & 0,50 \\
R1.4 & 1,23 & 1,58 & 1,39 \\
R2.1 & 0,64 & 0,69 & 0,76 \\
R2.2 & 2,08 & 1,74 & 1,72 \\
R2.3 & 100 & 100 & 100 \\
R3.1 & 2,42 & 2,54 & 2,24 \\
R3.2 & 0,02 & 0,04 & 0,20 \\
R.3.3 & 63,41 & 70,89 & 78,88 \\
\hline
\end{tabular}

Source : processed data, 2019

In the education dimension, PT. Sarana Multigriya Finansial has organized grants, scholarships, education and training, and research related to PT. Sarana Multigriya Finansial for employees, from 2016 to 2018, has carried out publications and promotions to the public to provide public awareness.

In the dimension of Justice, PT. Sarana Multigriya Finansial has made funding in the form of profit-sharing and partnership. Data from 2016 to 2018, 
Budi Sukardi, Fachrurazi, and Supriyanto

PT. Sarana Multigriya Finansial earns a lawful income from the total income received during the year. In the public interest dimension, PT. Sarana Multigriya Finansial has made investments and social services to fulfill the community's public interest and social welfare.

\section{The Sharia Maqashid Value Calculation of the Sharia Non- banking Financial Industry}

The Sharia Maqashid value calculation of the Sharia IKNB is as table 6:

Table 6. Indonesian Sharia Non-banking Financial Industry's Performance

Based on Each Sharia Maqashid's Performance Indicator Year 2016-2018 (\%)

\begin{tabular}{|c|c|c|c|c|c|c|c|c|c|c|c|c|c|}
\hline \multirow{2}{*}{ No } & \multirow{2}{*}{ IKNB } & \multicolumn{4}{|c|}{01} & \multicolumn{3}{|c|}{02} & \multicolumn{3}{|c|}{03} & \multirow[t]{2}{*}{ MSI } & \multirow[t]{2}{*}{ Rank } \\
\hline & & R1.1 & R1.2 & R1.3 & R1.4 & $\mathrm{R} 2.1$ & $\mathrm{R} 2.2$ & $\mathrm{R} 2.3$ & R3.1 & $\mathrm{R} 3.2$ & R3.3 & & \\
\hline 1 & Takaful & 0,0 & 0,0 & 0,0 & 0,7 & 45,2 & 0,0 & 100 & 1,0 & 3,7 & 18,4 & 169,0 & 3 \\
\hline 2 & Pegadaian & 0,1 & 0,0 & 0,9 & 2,8 & 10,6 & 0,0 & 100 & 5,0 & 0,0 & 2,8 & 122,2 & 5 \\
\hline 3 & DPLK BMI & 0,0 & 0,0 & 0,0 & 0,0 & 19,2 & 0,0 & 100 & 5,2 & 0,0 & 100,1 & 224,5 & 1 \\
\hline 4 & $\begin{array}{l}\text { Reindo } \\
\text { Syariah }\end{array}$ & 0,0 & 0,0 & 0,0 & 8,3 & 0,0 & 0,0 & 100 & 4,2 & 17,3 & 72,2 & 202,0 & 2 \\
\hline 5 & SMF & 0,3 & 0,3 & 0,5 & 1,4 & 0,8 & 1,7 & 100 & 2,2 & 0,2 & 78,9 & 186,3 & 4 \\
\hline
\end{tabular}

Source : processed data, 2019

From the calculation results based on each performance indicator of Maqashid Syariah, the highest achievement ranking of the ultimate goal of sharia is DPLK Muamalah, followed by PT. Reindo Syariah (Reinsurance Company), third in Asuransi Takaful Indonesia, PT. Sarana Multigriya Finansial (Secondary Financing Company), and the last rank is Pegadaian Indonesia. 


\section{The inclusive contribution of sharia maqashid towards the sustainable development of the sharia non-banking financial industry in indonesia}

The inclusive concept of sharia's ultimate goal is to reduce the lack of access to financial services. The sharia maqashid inclusive is the provision of access to people who have been marginalized and marginalized from the financial market and institutional services such as the poor, small, and medium business groups, which should be an enlightening focus.

In Islam, inclusion focuses on two things, first, risk sharing and redistribution of wealth. These two things distinguish how Islam views Islamic financial inclusion with inclusion in the conventional financial industry. These two things also almost escaped from the non-Islamic bank financial industry's activities, which seem to only pursue margins and profits without paying attention to the principle of fairness of the transacting actors and social responsibility.

Thus, the Islamic finance revolution emerged by providing tailored products and financial services that enable the poor to expand and diversify their economic activities, increase incomes, and improve social welfare. Poverty reduction through the development of the Sharia IKNB with an operational scope and values adhered to by Islamic Sharia's guidance is certainly very relevant for Indonesia, where most of the population is Muslim.

Opening access to financial services to the poor is not an easy task to do. As the providers of financial products, formal institutions face high transaction costs and the risk of default on loan repayments. Simultaneously, the poor also face obstacles in accessing legal institutions due to various factors. The physical and financial infrastructure is generally very limited with minimal quality, especially for those who are marginalized and live in areas not touched by the financial industry. 
To overcome the structural poverty that has been a prominent unfinished issue and often neglected by the state, it requires the ability and sensitivity to respond to the low class' turmoil by the sustainable economy, environment, and financial industry media. The Sharia IKNB, as the forerunner of the economic development agent, must improve the structural poverty system and become the leader in achieving the highest goals of sharia that focus and have an orientation towards the sustainability of human life, nature, economic resources, creative and all aspects of life.

\section{Conclusion}

The study results show the highest five ranks of Sharia Maqashid Index performance calculation, namely, in respective order, DPLK Muamalah, Reindo Syariah, Asuransi Takaful Indonesia, Sarana Multigriya Finansial, and lastly is Pegadaian Indonesia.

The inclusive contribution of sharia maqashid to the sharia non-banking financial industry in Indonesia is the ability to achieve economic sustainability, the environment, and the media for the lower-level public finance industry, improving structural poverty.

To overcome the structural poverty that has been a prominent unfinished issue and often neglected by the state, it requires the ability and sensitivity to respond to the low class' turmoil by the sustainable economy, environment, and financial industry media. The Sharia IKNB, as the forerunner of the economic development agent, must improve the structural poverty system and become the leader in achieving the highest goals of sharia that focus and have an orientation towards the sustainability of human life, nature, economic resources, creative and all aspects of life.

\section{References}

'Asyur, Ibnu. 2000. Maqashid Asy-Syariah Al-Islamiyyah. Yordania: Darun Nafais. 
Ahmad, Khurshid. 1976. Economic Development in an Islamic Framework. Jeddah: King Abdul Aziz University.

Al-Ghazali. 1991. Turathuna Al-Fikri Bayna Al-Shar' Wa Al-'Aql. Kairo: Dar alShuruq.

Al-Syatibi. 1900. Al-Muwafaqat fi Ushul al-Syari'ah. Kairo: Musthafa Muhammad.

Antonio, Muhammad Syafii, Yulizar D. Sanrego, dan Muhammad Taufiq. 2012. "An Analysis of Islamic Banking Performance: Maqashid Index Implementation in Indonesia and Jordania." Journal of Islamic Finance 1 (1): $\quad$ 12-29. $\quad$ http://journals.iium.edu.my/iiibfjournal/index.php/jif/article/view/2.

Bonin, John P., Iftekhar Hasan, dan Paul Wachtel. 2005. "Bank performance, efficiency and ownership in transition countries." Journal of Banking \& Finance 29 (1): 31-53. https://doi.org/10.1016/j.jbankfin.2004.06.015.

Chapra, M. Umer. 1993. Islam and Economic Development. Islamabad: The International Institute of Islamic Thought.

——_. 2001. The Future of Economics: An Islamic Perspective. Leicester: The Islamic Foundations.

Chapra, M. Umer, dan Habib Ahmed. 2008. Corporate Governance Lembaga Keuangan Syariah. Jakarta: Bumi Aksara.

Fasy, 'Allal. 1993. Maqashid Asy-Syariah Al-Islamiyyah Wa Makarimuha. 5th ed. Beirut: Darul Garb Al-Islamy.

Fauzi, Akhmad. 2004. Ekonomi Sumber Daya Alam dan Lingkungan: Teori dan Aplikasi. Jakarta: Gramedia Pustaka Utama.

Fazlurrahman. 1984. Islam. Bandung: Pustaka.

Fishburn, Peter C. 1967. A Problem-Based Selection of Multi-Attribute Decision Making Methods. New Jersey: Blackwell Publisihing.

Hameed, Shahul, Bakhtiar Alrazi, dan Sigit Pramono. 2004. "Alternative Disclosure and Performance Measures for Islamic Banks." Second Conference on Administrative Sciences: Meeting the Challenges of the Globalization Age. Dhahran Saudi Arabia.

Heal, Geoffrey. 1999. Valuing the Future: Economic Theory and Sustainability. New York: Columbia University Press. 
Hussain, Mostaque, dan Zahirul Hoque. 2002. "Understanding Non-Financial Performance Measurement Practices in Japanese Banks." Accounting, Auditing \& Accountability Journal 15 (2): 162-83. https://doi.org/10.1108/09513570210425583.

Iqbal, Munawar, Ausaf Ahmad, dan Tariqullah Khan. 1998. Challenges Facing Islamic Banking. First. Jeddah: King Fahd National Library IRTI Islamic Developmen Bank.

Jauziyah, Ibnu Qayyim. 1973. I'lamul Muwaqqi'in 'an Rabbil Alamin. Diedit oleh Thaha Abdur Rauf Sa'd. Beirut: Darul Jail.

Jaya, Asafri. 1996. Konsep Maqashid al-Syari'ah Menurut al-Syathibi. Jakarta: Raja Grafindo Persada.

Kuppusamy, Mudiarasan, Ali Salman Saleh, dan Ananda Samudhram. 2010. "Measurement of Islamic Banks Performance Using a Shariah Conformity and Profitablity Model." Review of Islamic Economics 13 (2): 35-48.

Kusumadewi, Sri, Sri Hartati, Agus Harjoko, dan Retantyo Wardoyo. 2006. Fuzzy Multi-Attribute Decision Making (Fuzzy MADM). Yogyakarta: Graha Ilmu.

MacCrimmon, K. R. 1968. "Decision Making Among Multiple-Attribute Alternatives: A Survey and Consolidated Approach." Advanced Research Project Agency. Santa Monica California: RAND Corporation.

Mannan, Muhammad Abdul. 1980. The Objective of Islamic Banks. Dhaka Bangladesh: Ins Thought of Islamic Banks.

Mohammed, Mustafa Omar, dan Dzuljastri Abdul Razak. 2008. "The Performance Measures of Islamic Banking Based on the." IIUM International Accounting Conference (INTAC IV) , Putra Jaya Marroitt 1967 (June): 1-17.

Mohammed, Mustafa Omar, dan Fauziah Md Taib. 2015. “Developing Islamic Banking Performance Measures Based on Maqasid al-Shari'ah Framework: Cases of 24 Selected Banks." Journal of Islamic Monetary Economics and Finance.

Rohmati, Dani, Rachmasari Anggraini, dan Tika Widiastuti. 2018. "Maqāṣid alSharīah sebagai Landasan Dasar Ekonomi Islam." Economica: Jurnal $\begin{array}{llll}\text { Ekonomi } & \text { Islam } & 9 & \text { (2): }\end{array}$ https://doi.org/10.21580/economica.2018.9.2.2051. 
Salim, Emil. 1990. Konsep Pembangunan Berkelanjutan. Jakarta: Gramedia Pustaka Utama.

Santoso, Singgih, dan Fandy Tjiptono. 2001. Riset Pemasaran: Konsep dan Aplikasi SPSS. Jakarta: PT. Elex Media Komputindo.

Seçme, Neşe Yalçin, Ali Bayrakdaroğlu, dan Cengiz Kahraman. 2009. "Fuzzy Performance Evaluation in Turkish Banking Sector Using Analytic Hierarchy Process and TOPSIS." Expert Systems with Applications. https://doi.org/10.1016/j.eswa.2009.03.013.

Shahul, H.M.I. 2001. "Different Worldview Needs Different Accounting." Kota Bahru Kelantan Malaysia.

Shidiq, Ghofar. 2009. "Teori Maqashid Al-Syari'ah Dalam Hukum Islam." Majalah Ilmiah Sultan Agung.

Siddiqi, Nejatullah. 1980. The Issues of Islamic Economics. Lahore Pakistan.

Siddiqui, S.H. 2001. “Islamic Banking: True Models of Financing.” New Horizon 109: 21-22.

Sutamihardja. 2004. "Perubahan Lingkungan Global." Sekolah Pascasarjana IPB.

Swasono, Sri-Edi. 2010. Ekspose Ekonomika Mewaspadai Globalisasi dan Pasar Bebas. Yogyakarta: Pusat Studi Ekonomi Pancasila UGM.

Wasyith, Wasyith. 2017. "Beyond Banking: Revitalisasi Maqāṣid dalam Perbankan Syariah." Economica: Jurnal Ekonomi Islam 8 (1): 1. https://doi.org/10.21580/economica.2017.8.1.1823.

Yubi, Muhammad Saad. 1998. Maqashid asy-Syariah al-Islamiyah Wa 'Alaqatuha Bil Adillah Asy-Syar'iyyah. Cetakan 1. KSA: Darul Hijrah Lin Nasyr Wat Tauzi'.

Yuwono, Sony. 2004. Petunjuk Praktis Penyusunan Balance Scorecard Menuju Organisasi yang Berfokus pada Strategi. Jakarta: PT Gramedia Pustaka Utama.

Zahrah, Muhammad Abu. 1958. Ushul Al-Fiqh. Kairo: Darul Fikri al-Araby. Zuhaili, Wahbah. 1997. Al-Fiqh al-Islâmi wa Adillatuhu. Beirut: Dâr al-Fikr. 
Budi Sukardi, Fachrurazi, and Supriyanto 